\title{
Starting torque and torque ripple reduction using SVPWM based vector control of induction motor with nine-level cascaded multilevel Inverter fed with solar PV power
}

\author{
Shashibhushan ${ }^{1}$, Savita Sonoli ${ }^{2}$ \\ ${ }^{1}$ Departement of ECE, Sir MVIT, India \\ ${ }^{2}$ Departement of ECE, RYM Engineering College, India
}

\begin{tabular}{l}
\hline Article Info \\
\hline Article history: \\
Received Nov 27, 2018 \\
Revised Jan 29, 2019 \\
Accepted Mar 14, 2019 \\
\hline Keywords: \\
Multilevel inverter \\
Multilevel space vector pulse \\
width modulation \\
Torque ripple reduction \\
Vector control of induction \\
motor
\end{tabular}

\begin{abstract}
This paper is an attempt to develop an Induction Motor Drive System with Multilevel Inverter topology for reduced torque ripple application. A Nine level-cascaded multilevel inverter is developed for the induction motor drive with SVPWM control powered by boost converter fed using solar PV supply. The SVPWM control based implementation of vector control using a multilevel inverter topology needs a multilevel SVPWM control technique, which is implemented in this paper. The Solar power supplied is applied with the MPPT technique and the supplied DC power is fed to the three phase cascaded 9 level multilevel inverter. The vector control of induction motor is carried out using the SVPWM technique on the multilevel topology. The torque ripple reduction in the output is observed and compared with the vector control of induction motor. Matlab based implementation is carried out and the results are tabulated and inferred.
\end{abstract}

Copyright (C) 2019 Institute of Advanced Engineering and Science. All rights reserved.

\section{Corresponding Author:}

Shashibhushan, Departement of ECE, Sir MVIT, International Airport Road, Hunasamaranahalli, Bengaluru, Karnataka 562157, India Email: shashigadigi1234@gmail.com

\section{INTRODUCTION}

Higher Electromagnetic compatibility in Multilevel Inverter and extensive use of Induction motors in the industries has brought in a higher demand of the multilevel inverter based induction motor drives. Solar based supply for these induction motor drives would increase the cost effectiveness of the induction motor drive systems since the power charges are going to be nullified except for the capital charges. A Five Level Inverter controlled by carrier based SPWM technique is used with open end winding 1HP induction motor [1]. Two three level inverter each comprising two 2 level inverters are placed each at one end of the open-ended induction motor. In [2] the number of switches are reduced but increasing the number of levels to six. A six level output is obtained by using a combination of a three level inverter with the two level inverter on either side of the open-ended induction motor. This topology needs three isolated power supplies as there are three two level inverters comprised in it.

A proposal of a structure for multilevel inverter topologies for stand alone PV system is seen in [3]. The multi-winding topology inverter gives better results compared to other types of multilevel inverters. The literature has presented the single phase PI controller based multilevel inverter for grid connection with lesser THD [4]. It has been presented a hexagonal and 12- sided polygonal voltage space vector with cascaded twolevel with induction motor drive in [5]. The THD value is minimized in this literature also. It has been ntroduced hybrid multilevel inverter topology for open-end winding induction machine using two level inverter in series with a capacitor-fed H-bridge cell, which eliminates 18 clamping diodes in [6]. 
A literature survey on multilevel inverter topologies and it control strategies are presented in [1]. Mainly topologies like diode clamped multilevel inverter, capacitor clamped and cascaded is considered and some PWM techniques also. This is helpful in analyzing different types of topologies and controls. The cascaded multilevel grid connected inverters has energy balance problems. A level shifted and phase-shifted PWMs with energy balance is studied in [7]. In 2014 modular multilevel-cascaded inverter driven induction motor without sensor is proposed [8]. Developed Dual inverter fed open-end stator winding induction motor drive with optimal pulse width modulation. It is discussed that distributed MPPT for grid connected modular cascaded H-Bridge multilevel PV inverter is applied [9].

In this paper 9- level multilevel inverter is proposed with SVPWM control for reduction of starting torque and torque ripple reduction. This also produces fast response of speed. The current ripple is also reduced and THD reduction as well at motor terminals. This paper is organized as follows, Section II discusses the Cascaded Multilevel Inverter and its switching sequence, Section III briefs about the SVPWM control of the 9 level multilevel inverter, Section IV discusses the proposed method in detail, and Section V discusses the results followed by Conclusion and References.

\section{CASCADED MULTILEVEL INVERTER}

There is a growing interest in multilevel topologies since they can extend the application of power electronics systems to higher voltages and power ratios. Multilevel inverters are the most attractive technology for the medium to high voltage range, which includes motor drives, power distribution, power quality and power conditioning applications. The general function of this multilevel inverter is to synthesize a desired voltage from several separate DC sources, which may be obtained from batteries, fuel cells, or solar cells. A particular advantage of this topology is that the modulation, control and protection requirements of each bridge are modular. The cascaded inverter has been largely studied and used in the various fields such as drives, transmission system and power conditioning.

Special Features of Cascaded Multilevel Inverter

a. The series structure allows a scalable, modularized circuit layout and packaging since each bridge has the same structure.

b. Requires the least number of components among all multilevel converters to achieve the same number of voltage levels without no extra clamping diodes or voltage balancing capacitors.

c. Soft switching techniques can be implemented which reduces switching losses and device stresses.

d. Switching redundancy for inner voltage levels is possible because the phase voltage output is the sum of each bridge's output.

e. Potential of shock is reduced due to the separate DC sources.

\subsection{Principle of operation cascaded multilevel inverter}

A relatively new power converter structure, cascaded-inverters with separate DC sources is introduced here. This new converter can avoid extra clamping diodes or voltage balancing capacitors. Each SDC is associated with a single-phase full bridge inverter. The AC terminal voltages of different level inverters are connected in series. The phase output voltage is synthesized by the sum of four inverter outputs. Each single-phase full bridge inverter can generate three level outputs, +Vdc, 0 , and -Vdc. This is made possible by connecting the DC sources sequentially to the AC side via the four semiconductor power devices. Each level of the full bridge converter consists of four switches. Using the top level as the example, by turning ON S1 and S4, yields V1 = +Vdc. By Turing ON S2 and S3, yields V1 = -Vdc. Turning OFF all switches yields $\mathrm{Vdc}=0$. Similarly, the AC output voltage at each level can be obtained in the same manner. Minimum harmonic distortion can be obtained by controlling the conducting angles of switches at different inverter levels.

Single Phase Five Level CMLI Topology In five level cascaded multilevel inverter, four separate DC sources (n-1) are used. Thus, four full bridge inverters are connected in series to obtain the five levels of output as 0 , VDC, 2VDC, 3VDC and 4VDC. The $\mathrm{H}$ bridges are named as A, B, C and D. The switching pattern of the power switches in each $\mathrm{H}$ bridge is same as described for the single phase three level cascaded inverter except the switches are progressed up to four bridges from bridges A to D.

Int J Pow Elec \& Dri Syst, Vol. 10, No. 2, June 2019 : 1123 - 1132 


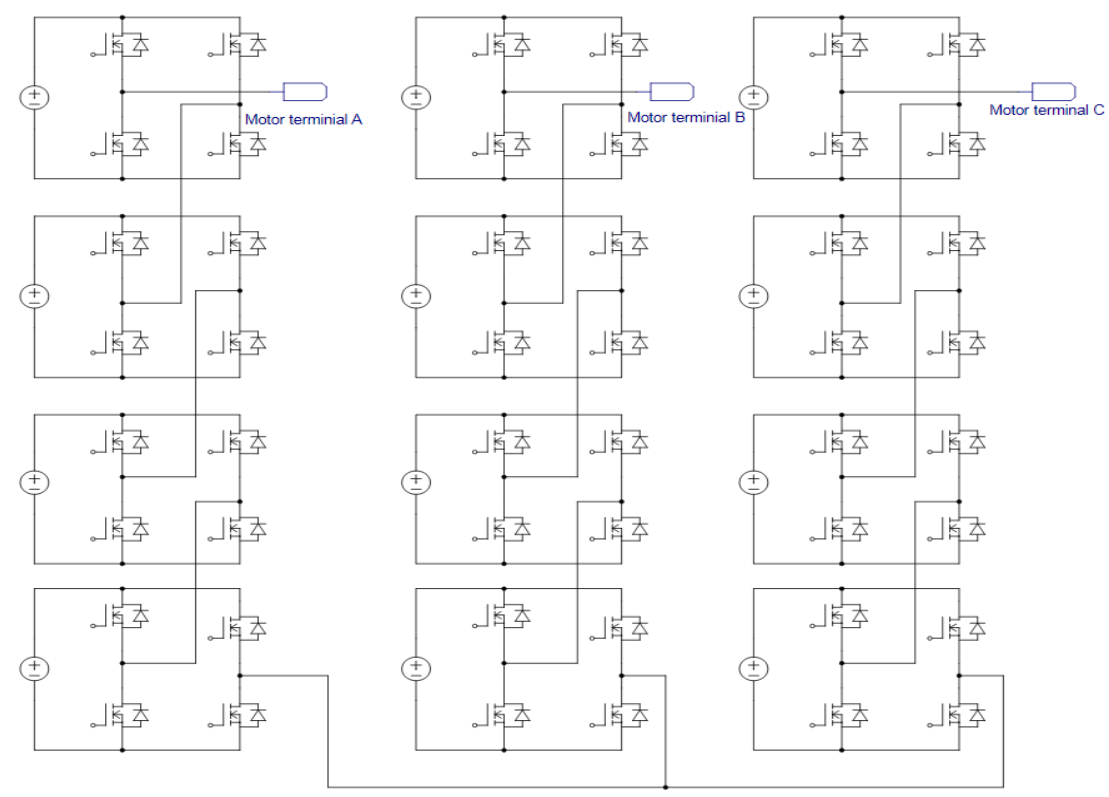

Figure 1. Cascaded multilevel inverter with 9-level output

\section{SVPWM CONTROL OF NINELEVEL INVERTER}

The calculations for the 7 level inverter is as discussed in [8] and calculation is extended to 9 level inverter in this paper and the results are obtained. The hexagonal vectors can be divided into six major triangular sectors (I to VI). Only the first sector of the coordinate is used because the vectors located in the other sectors can be transformed to first sector by clockwise rotating by an angle of $\mathrm{k}^{*}(\mathrm{pi} / 3) \mathrm{k}=(1,2,3,4,5$ for sector 2 to 6$)$. As all the sectors are identical, only details of sector I is given in Figure.4. Usually, a (M+1)level inverter is discussed here as shown in Figure.4. By decomposing $V_{\text {ref into }} \mathrm{m}$ and $\mathrm{n}$ axis it is easy to obtain the $m$ and $n$ axis component of $V_{\text {ref }}$ as $V_{\text {rm }}$ and $V_{r n}$ as given next:

$$
\operatorname{Vrm}=(2 * \mathrm{M} * \operatorname{Vref} / 3 \mathrm{Vdc}) \sin (\pi / 3-\theta)
$$

$$
\operatorname{Vrn}=\left(2 * M^{*} \operatorname{Vref} / 3 \mathrm{Vdc}\right) \sin (\theta)
$$

Where is speed of rotating reference vector?

As the number of levels is increased, the number of triangle increases in this way: $\mathrm{NT}_{\mathrm{T}}=6(\mathrm{~N}-1)^{2}$ For example a 7-level inverter, totaJl number of triangle is 216 , but the selection of triangle by the proposed method is very simple and generalized. Any space vJector located in any sector and in any triangle can Jbe calculated easily from and the value Vrm and Vrn explained below. Assuming Vref and should be suJch that it lies in the rectangular area specified by DEGF shown in Figure. 4. After calculating $V_{r m}$ and $V_{r n}$, caJlculate the lower rounded integer value ( $m$ and $n$ ) as shown below: Say, $V_{r m}=2.6 \& V_{r n}=1.85$.

Assuming $m=\operatorname{int}(2.6)=2 \& n=\operatorname{int}(1.85)=1$ These $m$ and $n$ are defined by vector $(m, n)$ in $m-n$ axis. If $\left(V_{r m}+\right.$ $\left.\mathrm{V}_{\mathrm{rn}}\right)<=(\mathrm{m}+\mathrm{n}+1)$ then Vref located in the left bottom triangle DEF, otherwise the triangle EFG.

Dwelling Time Calculation

The dwelling time calculation for each switching state is very simple and generalized. Suppose at any instant the Vref located in the Triangle GEF shown in Figure.4. The corresponding three nearest space vectors are $\left(\mathrm{m}_{1}, \mathrm{n} 1\right),\left(\mathrm{m}_{2}, \mathrm{n} 2\right)$ and $\left(\mathrm{m}_{3}, \mathrm{n} 3\right)$. According to voltage-time balance equation it can be solve three dwelling time $\mathrm{T}_{1}, \mathrm{~T}_{2}$, and $\mathrm{T}_{3}$ as follows:

$$
\begin{aligned}
& \mathrm{n}_{1} * \mathrm{~T}_{1}+\mathrm{n}_{2} * \mathrm{~T}_{2}+\mathrm{n}_{3} * \mathrm{~T}_{3} \\
& \mathrm{~m}_{1} * \mathrm{~T}_{1}+\mathrm{m}_{2} * \mathrm{~T}_{2}+\mathrm{m}_{3} * \mathrm{~T}_{3}
\end{aligned}
$$


Where TPWM is PWM time period?

The method demonstrated how simple it is to determine the triangle that reference voltage falls in and to calculate the dwell times. More importantly, the algorithm has another few features:

a. It is a general algorithm, which can be used for inverters with any number of voltage levels up to seven level and eventually can extend beyond seven level with some modification of inverter power circuit;

b. There are only two sets of equations for dwell time calculation. Compared with the Cartesian coordinate system where there are many sets of different equations for the Calculation of the dwell time.

c. The proposed algorithm considers over-modulation case also. It is easy to judge whether SVPWM is in over- modulation region or not, simply by checking the following inequality:

if $\left(\mathrm{V}_{\mathrm{rm}}+\mathrm{V}_{\mathrm{rn}}\right)>\mathrm{M}$, it becomes over-modulation.

A useful method to handle this situation is to multiply the original vector say $V_{\mathrm{rm}}$ and $\mathrm{V}_{\mathrm{rn}}$ by a factor $\mathrm{M}$ /

$\left(\mathrm{V}_{\mathrm{rm}}+\mathrm{V}_{\mathrm{rn}}\right)$ and the consequent steps are same as discussed.

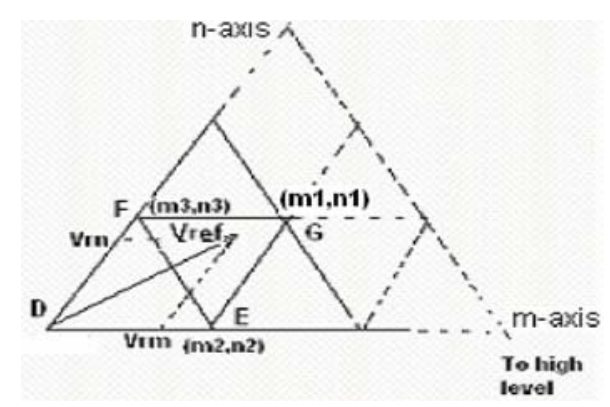

Figure 2. The vector selection for the time calculated

The induction motors are very common because they are inexpensive and robust, finding use in everything from industrial applications such as pumps, fans, and blowers to home appliances. Traditionally, induction motors have been run at a single speed, which was determined by the frequency of the main voltage and the number of poles in the motor. Controlling the speed of an induction motor is far more difficult than controlling the speed of a DC motor since there is no linear relationship between the motor current and the resulting torque as there is for a DC motor. The technique called vector control can be used to vary the speed of an induction motor over a wide range. In the vector control scheme, a complex current is synthesized from two quadrature components, one of which is responsible for the flux level in the motor, and another, which controls the torque production in the motor. Essentially, the control problem is reformulated to resemble the control of a DC motor. Vector control offers a number of benefits including speed control over a wide range, precise speed regulation, fast dynamic response, and operation above base speed. The vector control algorithm is based on two fundamental ideas. The first is the flux and torque producing currents. An induction motor can be modeled most simply (and controlled most simply) using two quadrature currents rather than the familiar three phase currents actually applied to the motor. These two currents called direct (Id) and quadrature (Iq) are responsible for producing flux and torque respectively in the motor. By definition, the Iq current is in phase with the stator flux, and Id is at right angles.

Of course, the actual voltages applied to the motor and the resulting currents are in the familiar three-phase system. The move between a stationary reference frame and a reference frame, which is rotating synchronous with the stator flux, becomes then the problem. This leads to the second fundamental idea behind vector control. The second fundamental idea is that of reference frames. The idea of a reference frame is to transform a quantity that is sinusoidal in one reference frame, to a constant value in a reference frame, which is rotating at the same frequency. Once a sinusoidal quantity is transformed to a constant value by careful choice of reference frame, it becomes possible to control that quantity with traditional proportional integral (PI) controllers.

Space vector modulation (SVM) is based on vector selection in the q-d stationary reference frame. The commanded voltage vector is defined by equation-1.to 4 . The commanded vector is plotted along with the vectors obtainable by the inverter. The desired vector $\mathrm{V}^{\mathrm{s}^{*}}{ }_{\mathrm{qds}}$ shown at some point in time, but will follow

Int J Pow Elec \& Dri Syst, Vol. 10, No. 2, June 2019 : 1123 - 1132 
the circular path if a three phase set of voltages are required on the load. The first step in the SVM scheme is to identify the three nearest vectors.

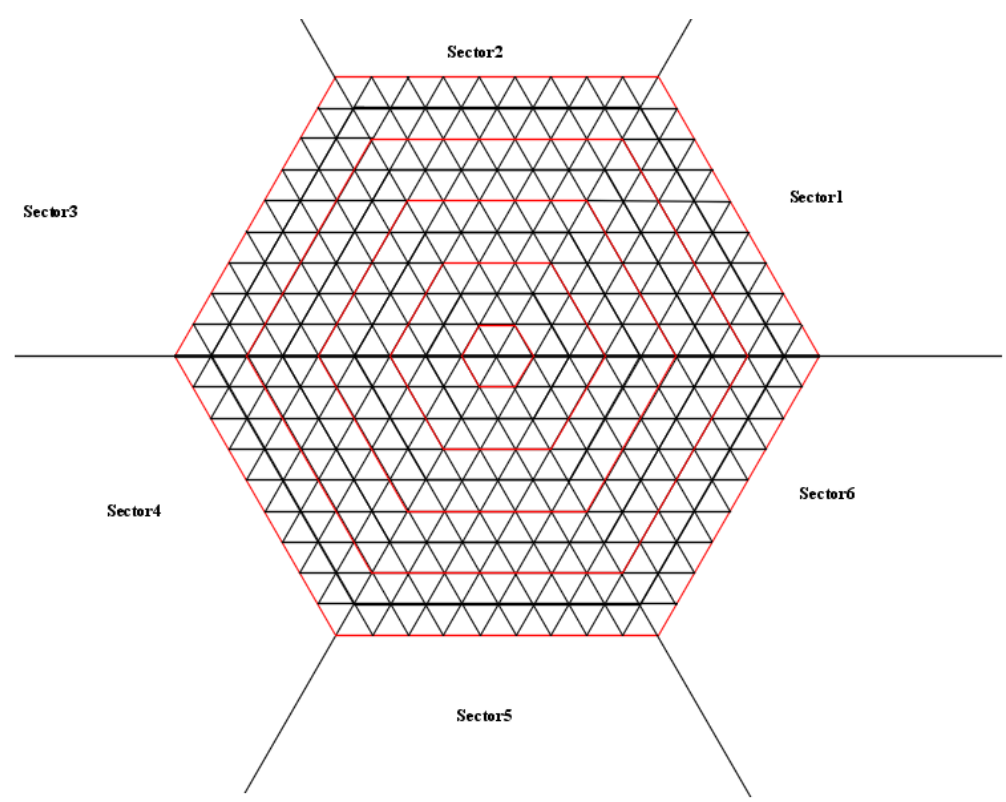

Figure 3. Hexagonal SVPWM extension for 9 level three-phase inverter

\section{RESULTS AND ANALYSIS}

The vector control of induction machine is done in simulation of MATLAB. Two cases are analyzed one is with two level inverters. The SVPWM is used here as the PWM modulation. Another case is with nine level cascaded multilevel inverter with SVPWM based vector control. And in nine level inverters is fed with solar based boost converter with incremental conductance algorithm. Both the cases are analyzed with 100 $\mathrm{rad} / \mathrm{sec}$ as reference speed and load torque is $50 \mathrm{Nm}$ from 0 to $1.5 \mathrm{secs}$. From $1.5 \mathrm{secs}$ to 2.5 secs it made as zero and then again from 2.5 to $3 \mathrm{secs}$ it is changed to $50 \mathrm{Nm}$. Figure. 2 shows the speed and torque characteristics of two-level and nine-level inverter based motor control with SVPWM. Speed of the two-level inverter reaches its stability at $1.1 \mathrm{secs}$. But nine level inverters reach at 0.4 secs. And initial torque intake reaches $1200 \mathrm{Nm}$. But in nine level inverters it reaches $560 \mathrm{Nm}$. And torque ripple also visibly less compared with two level inverters.

And Figure. 4 and Figure. 5 shows the current wave form of the motor with two-level inverter and nine-level inverter and two-level and 7 seven level comparison. Figure. 6 to 8 shows the THD analysis of the two-level seven level and nine level inverter fed motor current. 

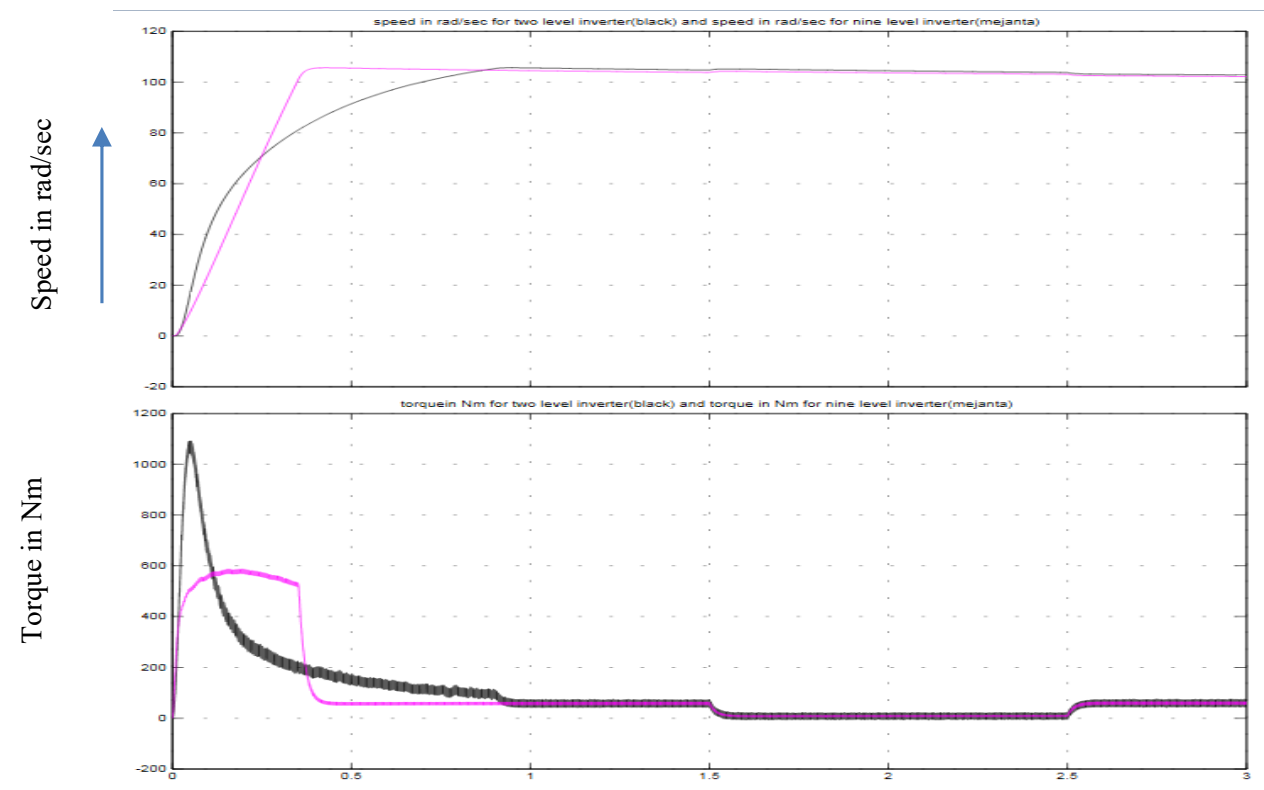

Figure 4. Speed and torque graph for 2-level (black) and 9-level (magenta) inverter

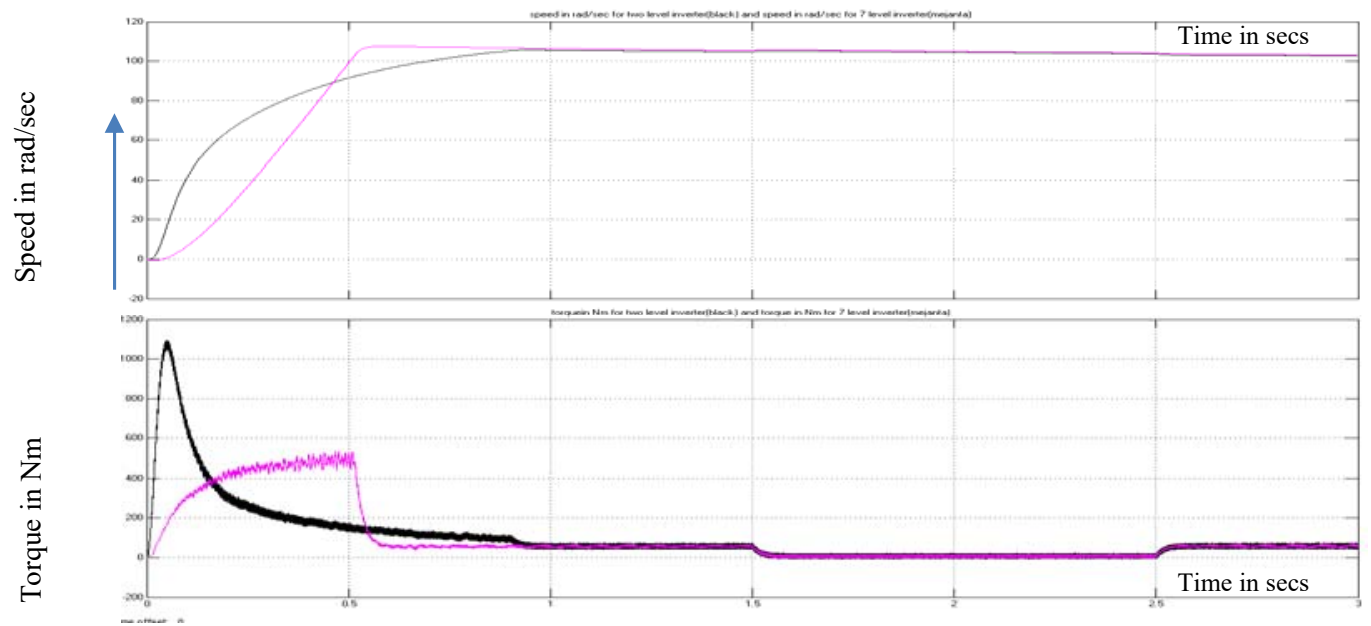

Figure. 5 Speed and torque graph for 2-level (black) and 7-level (magenta) inverter 
siprid
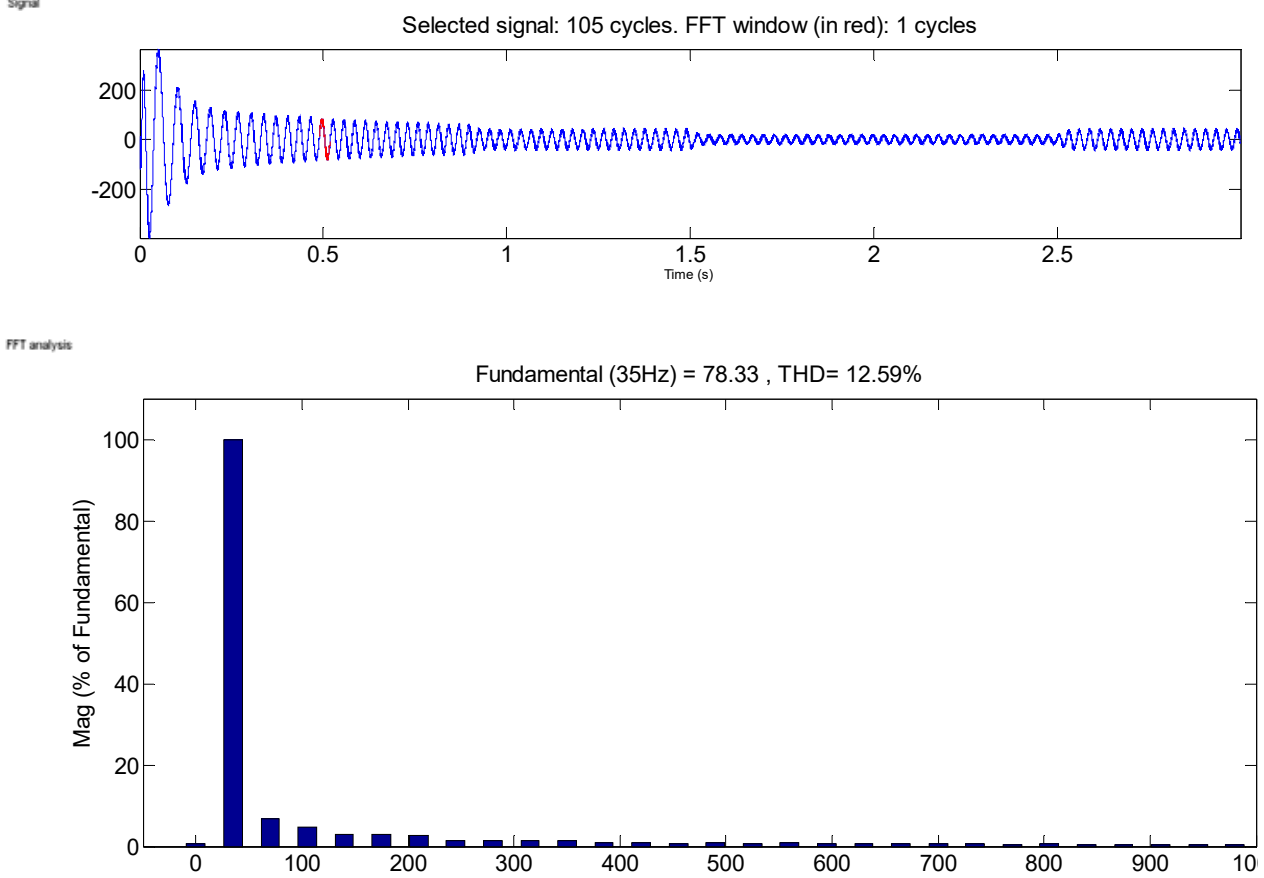

Figure 6. Two-level inverter with vector control THD analysis.
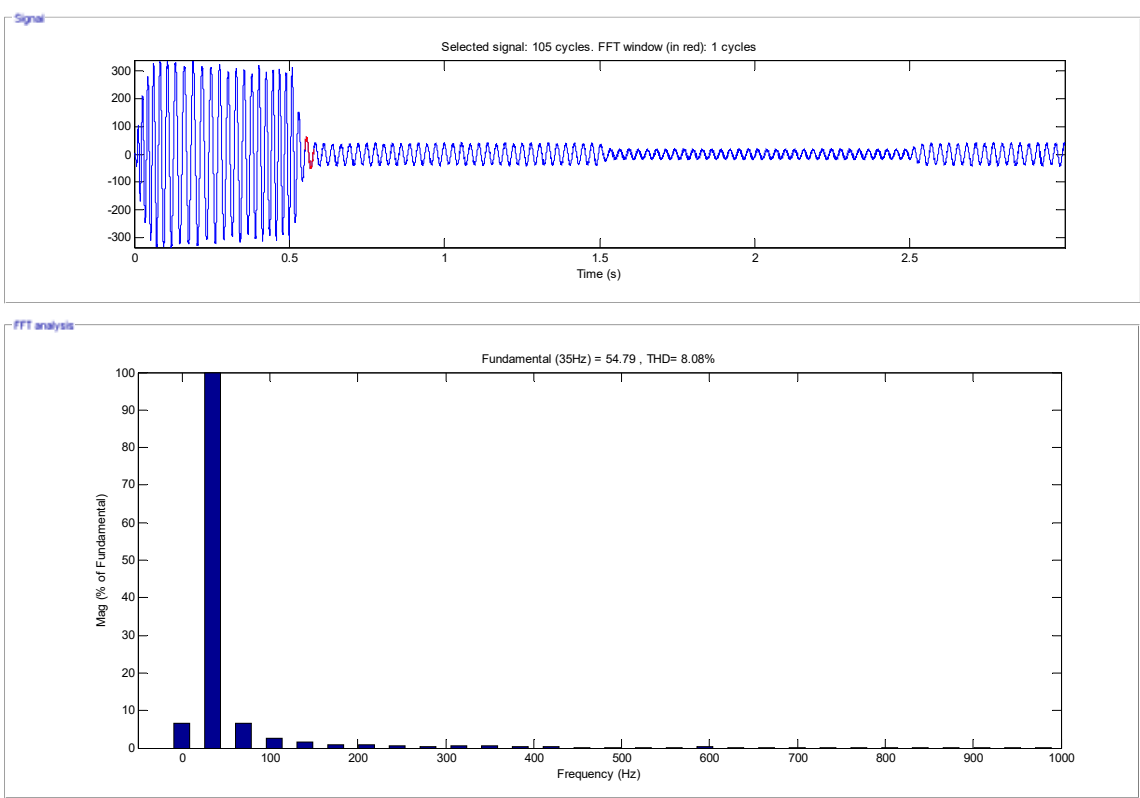

Figure 7. 7-level inverter with vector control THD analysis 
Signal

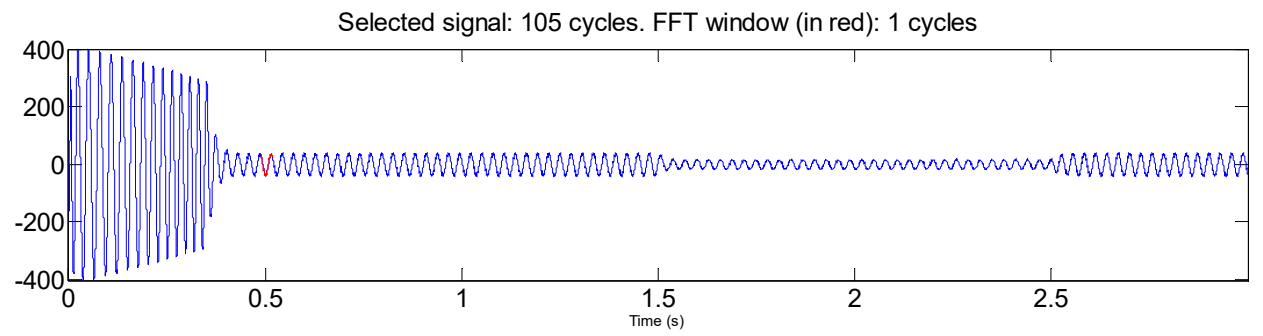

FFT analysis

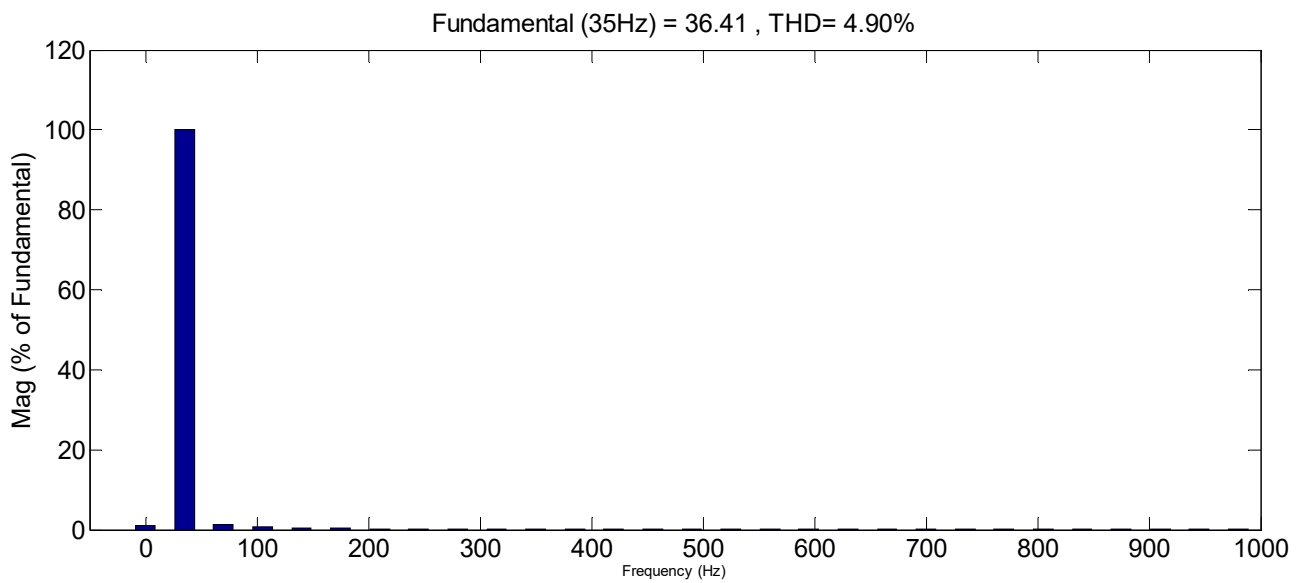

Figure 8. Nine-level inverter with vector control THD analysis

The THD value of two level inverter current is $12.59 \%$ and $4.9 \%$ in nine level inverter current. Table 1 shows the above said performance comparison.

Table 1. Performance comparison

\begin{tabular}{ccccc}
\hline & Settling time in sec & Rise time in secs & THD in $\%$ & Starting torque in Nm \\
\hline 2-Level & 1.1 & 1.2 & 12.59 & 1200 \\
7-level & 0.55 & 0.6 & 8.08 & 570 \\
9-level & 0.4 & 0.5 & 4.9 & 560 \\
\hline
\end{tabular}

The Table 2 depicts the PV panel ratings that are introduced in the implementation. The converter used is a boost converter that works with the incremental conductance MPPT algorithm.

Table 2. Solar power Specification

\begin{tabular}{cc}
\hline Parameters & Specifications \\
\hline PV panel type & Sunpower SPR-305-WHT \\
number of cells & 1 \\
Voc in V & 64.2 \\
Isc in A & 5.96 \\
Vmpp in V & 54.7 \\
Impp in A & 5.58 \\
MPPT technique & Incremental Conductance \\
Converter type & Boost \\
DCDC output & $100 \mathrm{~V}$ \\
\hline
\end{tabular}

The Induction motor used for the implementation is provided in Table 3. The three phase motor ratings are chosen which suits the power delivered from the motor. The SVPWM method implemented on the induction motor decreases the harmonic content in the output.

Int J Pow Elec \& Dri Syst, Vol. 10, No. 2, June 2019 : 1123 - 1132 
Table 3. Motor parameters

\begin{tabular}{cc}
\hline Parameters & Specification \\
\hline Power & $50 \mathrm{HP}$ \\
Nominal RMS Voltage in V & 460 \\
Frequency & $50 \mathrm{~Hz}$ \\
Number of poles & 2 \\
\end{tabular}

\section{CONCLUSION}

The vector control of induction motor is fed with two-level inverter and nine level inverters and SVPWM technique is used control it. The nine-level inverter is fed with solar and boost converter as input as the number of DC sources are high. The performance parameters like settling time, rise time, THD and starting torques are reduced in proposed nine level solar-fed SVPWM inverter.

\section{REFERENCES}

[1] Naumanen J. Korhonen P. Silventoinen J. Pyrho"nen, "Mitigation of high du/dt-originated motor overvoltages in multilevel inverter drives", IET Power Electronics, 2009, Page No. 681- 689.

[2] A. Chitra, S. Himavathi, "Reduced switch multilevel inverter for performance enhancement of induction motor drive with intelligent rotor resistance estimator", IET Power Electronics, 2015, pp.1-10.

[3] Sérgio Daher, Jürgen Schmid, and Fernando L. M. Antunes, "Multilevel Inverter Topologies for Stand-Alone PV Systems", IEEE Transactions on Industrial Electronics, Vol. 55, No. 7, July 2008.

[4] Jeyraj Selvaraj and Nasrudin A. Rahim, "Multilevel Inverter for Grid-Connected PV System Employing Digital PI Controller", IEEE Transactions on Industrial Electronics, Vol. 56, No. 1, January 2009.

[5] Anandarup Das, K. Sivakumar, Rijil Ramchand, Chintan Patel and K. Gopakumar, "A Combination of Hexagonal and 12-Sided Polygonal Voltage Space Vector PWM Control for IM Drives Using Cascaded Two-Level Inverters", IEEE Transactions On Industrial Electronics, Vol. 56, No. 5, May 2009.

[6] K. Sivakumar, Anandarup Das, Rijil Ramchand, Chintan Patel and K. Gopakumar, "A Hybrid Multilevel Inverter Topology for an Open-End Winding Induction-Motor Drive Using Two-Level Inverters in Series With a CapacitorFed H-Bridge Cell”, IEEE Transactions On Industrial Electronics, Vol. 57, No. 11, November 2010.

[7] Javier Chavarría, Domingo Biel, Francesc Guinjoan, Carlos Meza, and Juan J. Negroni, "Energy-Balance Control of PV Cascaded Multilevel Grid-Connected Inverters under Level-Shifted and Phase-Shifted PWMs", IEEE Transactions on Industrial Electronics, Vol. 60, No. 1, January 2013.

[8] K.C Jana and Sujit Kumar Biswas,"A simple and Generalized SVPWM Control of Cascaded H-Bridge Multilevel Inverters", Journal of Electrical Engineering.

[9] Anubrata Dey, P. P. Rajeevan, Rijil Ramchand, K. Mathew, and K. Gopakumar, "A Space-Vector-Based Hysteresis Current Controller for a General n-Level Inverter-Fed Drive With Nearly Constant Switching Frequency Control”, IEEE Transactions On Industrial Electronics, Vol. 60, No. 5, May 2013.

[10] Amarendra Edpuganti \& Akshay K. Rathore, "A Survey of Low-Switching Frequency Modulation Techniques for Medium-Voltage Multilevel Converters", IACC ,2015 pp.1-8. 


\section{BIOGRAPHIES OF AUTHORS}

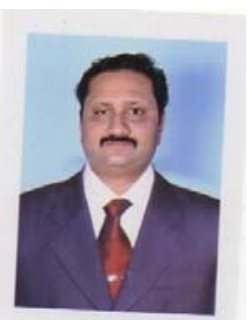

Shashibhushan with 14 years experience in academics is currently working as the Assistant Professor in Sir MVIT, Bangalore. He completed his B.E from RYMEC, Ballari and M.Tech from PDA College of Engineering, Gulbarga, and India.His research interests includes Power Electronics and Embedded System. He has published 10 Journals on the in different domains.

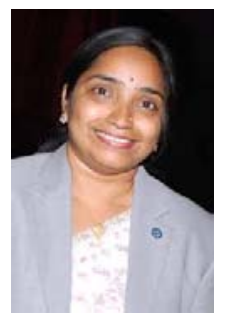

Dr. Savita Sonoli completed her Btech from BVB College of Engineering ,Dharwad,karnataka,M.Tech in National Institute of Technology and her PhD from S.K University ,Anantpur. Having a vast academic experience of 18 years and research experience of 6years she is now working as the Vice Principal and Profesor in Electronics and Comunication Engineering in RYMEC ,Ballari, Karnataka, India.She has published around 21 papers in her research área of embedded systems including both national and international levels. 